\title{
Research on Interfacial Bonding Properties and Engineering Applications of Polymer Modified Mortar
}

\author{
Zhihang Wang ${ }^{1}$, Jinyu Xu ${ }^{1,2}$, Wei Xia ${ }^{1}$, Zhe Huang ${ }^{1}$, Xin Meng ${ }^{1}$, Xing Xiaoguang ${ }^{1}$ \\ ${ }^{1}$ College of Aeronautics Engineering, Air Force Engineering University, Xi'an, Shaanxi, 710038, China \\ ${ }^{2}$ College of Mechanics and Civil Engineering, Northwestern Polytechnical University, Xi'an, Shaanxi, 710072, China
}

\begin{abstract}
Using the slotting method to process the interface of ordinary mortar, based on ordinary mortar specimens, new and old mortar bonding specimens were prepared, and the bond strength test was carried out. The effect of interface roughness on the bonding strength of VAE rubber powder modified mortar and styreneacrylic emulsion modified mortar was tested, and then the interfacial bonding properties of polymer modified mortar were studied. The test results show that the bonding strength of polymer-modified mortar increases with the increase of interface roughness; in engineering applications, the interface can be properly chiseled to increase the interface roughness, which is beneficial to the bonding of polymer-modified mortar firm. At the same time, the application prospects of VAE rubber powder modified mortar in the field of concrete anticorrosion, and the application prospect of styrene-acrylic emulsion modified mortar in the repair and freezethaw damage of concrete structure and anti-seepage treatment are prospected.
\end{abstract}

\section{Introduction}

Ordinary mortar is widely used in construction projects, and the amount is huge. A large amount of mortar is used for repairing, waterproofing and impermeability of underground projects, hydraulic structures, tunnels and other projects. There are many types of mortar, and its performance is continuously improved with the development of modern engineering. However, ordinary mortar is a typical brittle material. The lower tensile strength and flexural strength lead to poor toughness, and the lower bond strength causes easy cracking; the compressive strength and elastic modulus are high, the fold compression is relatively small, and the deformability is insufficient. If it is used as a repair material, it is easy to cause the interface to bond poorly and crack, resulting in limited use. For projects with high construction efficiency and durability requirements, the repair effect is poor and it is difficult to meet the requirements. Therefore, improving and stabilizing the quality of mortar is a real problem to be solved urgently in practical engineering.

Polymer-modified mortar is to add a small amount of polymer in the molding process of cement mortar, thereby improving the performance of mortar, improving the quality of use, and meeting the special needs of actual projects [1-3]. Compared with ordinary mortar, polymermodified mortar has high flexural strength, strong toughness, large deformability, and good durability such as wear resistance and corrosion resistance [4-6]. At the same time, the construction process is simple, easy to use, and firmly bonded to the base concrete. In recent years, a lot of research has been carried out on polymer modified mortars. Pan Wei et al. studied the bonding performance between mortar and cement-based composite materials mixed with different rubber powder. When the content of rubber powder is low, the tensile bonding strength of the mortar can be significantly improved [7]. Shaker et al. used SEM to study the durability of styrene-butadiene emulsion (SBR) modified concrete. It is believed that styrene-butadiene emulsion can not only improve the sulfate resistance of concrete, but also improve the water resistance and durability of concrete [8]. Pan Zhengkai studied the modification effect of styrene-butadiene emulsion, styrene-acrylic emulsion and VAE emulsion on waterproof mortar, and concluded that styrene-butadiene emulsion is not suitable for preparing waterproof mortar [9]. A large number of studies have focused on the mechanical properties and durability of polymer-modified mortars [10], while there are few studies on the interfacial adhesion properties of polymer-modified mortars.

Based on this, this article uses the slotting method to treat the interface of ordinary mortar, to study the effect of interface roughness on the bonding strength of two polymers (VAE powder, styrene-acrylic emulsion) modified mortar, and to explore the polymer modified mortar Interface bonding properties. At the same time, the application of VAE rubber powder modified mortar in the field of concrete anti-corrosion and the application of styrene-acrylic emulsion modified mortar in the repair and freeze-thaw damage of concrete structure and antiseepage treatment were introduced.

\section{Experiment}

\subsection{Experiment material}


Cement: P.O 42.5 ordinary Portland cement produced by Lantian Yaobai Special Cement Group Co., Ltd., its physical properties and chemical composition are shown in Table 1 and Table 2. Sand: Bahe sand, bulk density $2630 \mathrm{~kg} / \mathrm{m} 3$, bulk density $1450 \mathrm{~kg} / \mathrm{m} 3$, and mud content $1.1 \%$. Polymer: VAE rubber powder, styrene-acrylic emulsion, the technical specifications of the two are shown in Table 3 and Table 4. Water: ordinary tap water. Water reducer: Shaanxi Zhongyi Chemical's $40 \%$ solids polycarboxylate high performance water reducer mother liquor.

Table 1. Physical properties of P.O 42.5 ordinary Portland cement.

\begin{tabular}{|c|c|c|c|c|c|c|c|c|}
\hline \multirow{2}{*}{$\begin{array}{l}0.08 \mathrm{~mm} \text { Sieve } \\
\text { residue } \%\end{array}$} & \multicolumn{2}{|c|}{ Setting time $/ \mathrm{min}$} & \multicolumn{2}{|c|}{$\begin{array}{c}\text { Flexural } \\
\text { strength } / \mathrm{MPa}\end{array}$} & \multicolumn{2}{|c|}{$\begin{array}{c}\text { Compressive } \\
\text { strength } / \mathrm{MPa}\end{array}$} & \multirow{2}{*}{$\begin{array}{l}\text { Standard consistency } \\
\text { Water consumption } \\
\qquad / \mathrm{mL}\end{array}$} & \multirow{2}{*}{$\begin{array}{l}\text { Stability } \\
\text { (Boiling } \\
\text { method) }\end{array}$} \\
\hline & $\begin{array}{l}\text { Initial } \\
\text { setting }\end{array}$ & $\begin{array}{l}\text { Final } \\
\text { setting }\end{array}$ & $3 \mathrm{~d}$ & $28 \mathrm{~d}$ & $3 \mathrm{~d}$ & $28 \mathrm{~d}$ & & \\
\hline 4.2 & 163 & 264 & 5.4 & 6.9 & 23.5 & 46.2 & 190 & qualified \\
\hline
\end{tabular}

Table 2. P.O 42.5 ordinary Portland cement chemical composition.

\begin{tabular}{|c|c|c|c|c|c|c|c|}
\hline ingredient & $\mathrm{SiO}_{2}$ & $\mathrm{CaO}$ & $\mathrm{Al}_{2} \mathrm{O}_{3}$ & $\mathrm{Fe}_{2} \mathrm{O}_{3}$ & $\mathrm{f}-\mathrm{CaO}$ & $\mathrm{MgO}$ & $\mathrm{SO}_{3}$ \\
\hline percentage $/ \%$ & 23.16 & 64.85 & 5.64 & 4.63 & 0.28 & 1.68 & - \\
\hline
\end{tabular}

Table 3. Technical index of VAE rubber powder.

\begin{tabular}{|c|c|c|c|c|c|c|}
\hline Exterior & Solid content & $\begin{array}{c}\text { Ash } \\
\left(100{ }^{\circ} \mathrm{C}\right)\end{array}$ & $\begin{array}{c}\text { Bulk density } \\
/ \mathrm{g} / \mathrm{L}\end{array}$ & $\begin{array}{c}\text { The average } \\
\text { particle size } \\
/ \mathrm{um}\end{array}$ & $\mathrm{pH}$ value & $\begin{array}{c}\text { Minimum film } \\
\text { forming } \\
\text { temperature } /{ }^{\circ} \mathrm{C}\end{array}$ \\
\hline $\begin{array}{c}\text { White } \\
\text { powder }\end{array}$ & $\geq 98 \%$ & $10 \pm 2 \%$ & $400 \sim 600$ & $\geq 80$ & $6 \sim 8$ & 5 \\
\hline
\end{tabular}

Table 4. Technical specifications of styrene-acrylic emulsion.

\begin{tabular}{|c|c|c|c|c|c|}
\hline Exterior & $\begin{array}{c}\text { Solid } \\
\text { content }\end{array}$ & $\begin{array}{c}\text { Monomer } \\
\text { residue }\end{array}$ & $\begin{array}{c}\text { Viscosity / } \\
\mathrm{mPa} \cdot \mathrm{a}\end{array}$ & $\mathrm{pH}$ value & $\begin{array}{c}\text { Glass } \\
\text { transition } \\
\text { temperature } \\
/{ }^{\circ} \mathrm{C}\end{array}$ \\
\hline $\begin{array}{c}\text { Milky white liquid with } \\
\text { blue light }\end{array}$ & $(48 \pm 2) \%$ & $\leq 1.0 \%$ & $500 \sim 1500$ & $7.5 \sim 9.0$ & $14 \sim 23$ \\
\hline
\end{tabular}

\subsection{Experiment method}

Based on ordinary mortar test pieces, new and old mortar bonding test pieces were prepared. Mix the mortar, prepare a common mortar test piece (half " 8 " characters), standard curing for $28 \mathrm{~d}$, and then process the interface of the ordinary mortar. In this test, the slotting method (schematic diagram shown in Figure 1) is used to process the ordinary mortar interface. The bonding interface is cut at a certain depth and a fixed interval. This method is easy to control the construction quality and ensure the uniformity of the roughness. This article uses the roughness index to assess the interface roughness:

$$
\beta=\frac{n \Delta a b}{a b} \equiv \frac{n \Delta a}{a}
$$

In the formula: $\beta$ is the roughness index; $a$ is the length of the bonding surface; $b$ is the width of the bonding surface; $\Delta a$ is the average width of each groove; $\mathrm{n}$ is the number of cutting grooves in the a direction of the bonding surface. Figure 2 shows the cutout of the test piece. Table 5 is the roughness of each group of test pieces.

Table 5. Roughness of each group of test pieces.

\begin{tabular}{|c|c|c|c|}
\hline $\begin{array}{c}\text { Specimen } \\
\text { number }\end{array}$ & Polymer type & $\mathrm{n}$ & Roughness \\
\hline
\end{tabular}

\begin{tabular}{|c|c|c|c|}
\hline A0 & \multirow{4}{*}{ VAE powder } & 0 & 0 \\
\hline A1 & & 1 & 0.135 \\
\hline $\mathrm{A} 2$ & & 2 & 0.270 \\
\hline A3 & & 3 & 0.405 \\
\hline B0 & \multirow{4}{*}{$\begin{array}{l}\text { Styrene- } \\
\text { acrylic } \\
\text { emulsion }\end{array}$} & 0 & 0 \\
\hline $\mathrm{B} 1$ & & 1 & 0.135 \\
\hline $\mathrm{B} 2$ & & 2 & 0.270 \\
\hline B3 & & 3 & 0.405 \\
\hline
\end{tabular}

vertical view

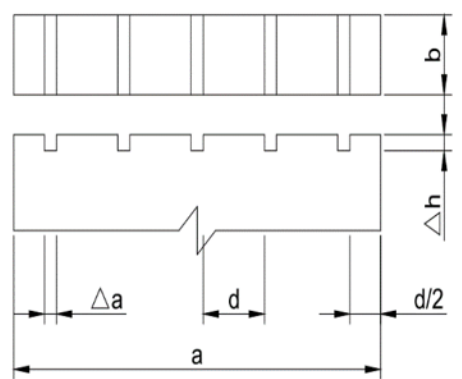

Front elevation

Figure .1. Schematic diagram of slotting method. 


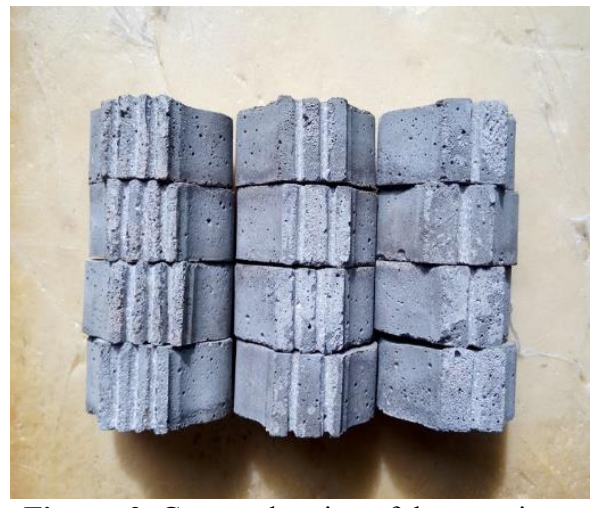

Figure. 2. Groove drawing of the test piece.

After weighing according to the mixing ratio in Table 6 (Table 7), pour sand and cement into the mixer and mix for 120 s, then mix and stir water, water reducer and VAE powder (styrene-acrylic emulsion) evenly, then pour in In the mixer, stir for 120 s to prepare VAE rubber powder (styrene-acrylic emulsion) modified cement mortar. Load the prepared modified cement mortar into the remaining half of the "8" shaped mold (as shown in Figure 3), prepare new and old mortar bonding test pieces, vibrate and compact, remove the mold after 24 hours of curing, and then remove the test piece Wet curing in the curing tank for $5 \mathrm{~d}$, and then put the test piece into the curing box for $23 \mathrm{~d}$ to obtain the " 8 " shaped test piece used in the adhesion test.

Table 6. VAE rubber powder modified mortar mix ratio.

\begin{tabular}{|c|c|c|c|c|}
\hline $\begin{array}{c}\text { cement } \\
/ \mathrm{g}\end{array}$ & $\begin{array}{c}\text { sand/ } \\
\mathrm{g}\end{array}$ & $\begin{array}{c}\text { Polymer- } \\
\text { cement } \\
\text { ratio }\end{array}$ & $\begin{array}{c}\text { Water } \\
- \\
\text { ceme } \\
\mathrm{nt} \\
\text { ratio }\end{array}$ & $\begin{array}{c}\text { Water } \\
\text { reducer }\end{array}$ \\
\hline 900 & 2400 & $10 \%$ & 0.38 & $1 \%$ \\
\hline
\end{tabular}

Table 7. Mix ratio of styrene-acrylic emulsion modified mortar.

\begin{tabular}{|c|c|c|c|c|}
\hline cement/g & sand/g & $\begin{array}{c}\text { Polymer- } \\
\text { cement } \\
\text { ratio }\end{array}$ & $\begin{array}{c}\text { Water- } \\
\text { cement } \\
\text { ratio }\end{array}$ & $\begin{array}{c}\text { Water } \\
\text { reducer }\end{array}$ \\
\hline 1100 & 2400 & $10 \%$ & 0.40 & $1 \%$ \\
\hline
\end{tabular}

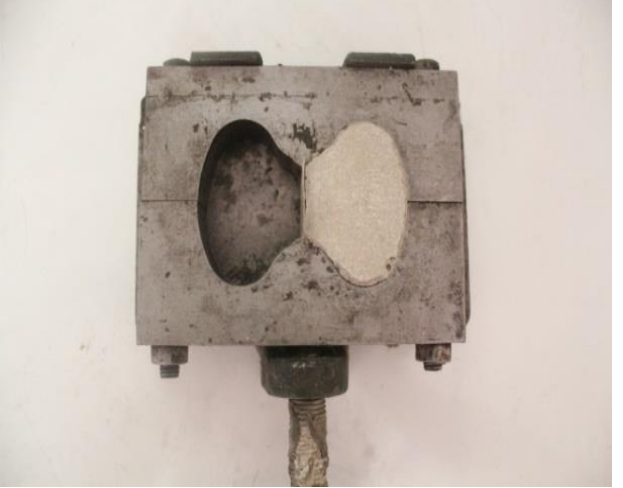

Figure. 3. Mold.

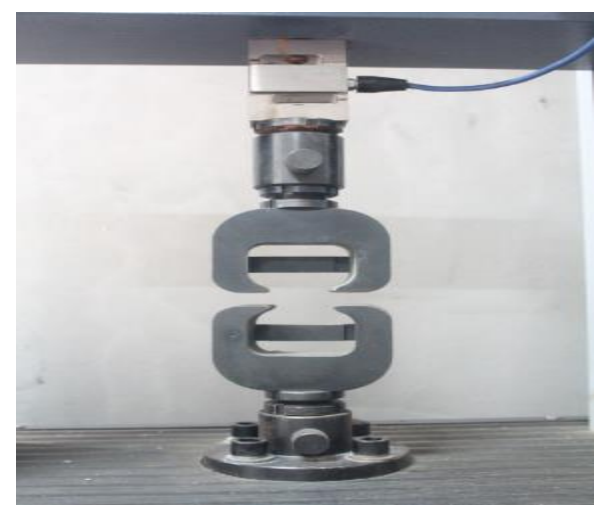

Figure. 4. Fixture.

The HS-3001B-S electronic precision servo tensile testing machine was selected to measure the bond strength, the test piece was placed on the fixture (as shown in Figure 4 ), and the test piece was evenly loaded at a speed of 5 $\mathrm{mm} / \mathrm{min}$, and the failure load was recorded. The calculation formula of bond strength is as follows:

$$
f=\frac{T}{S}
$$

Where: $\mathrm{f}$ is the bond strength, $\mathrm{T}$ is the load at failure, $\mathrm{s}=\mathrm{ab}$. The test results of the bonding strength of each group of test pieces are shown in Table 8 .

Table 8. Bonding strength of each group of test pieces.

\begin{tabular}{|c|c|c|c|}
\hline $\begin{array}{c}\text { Specimen } \\
\text { number }\end{array}$ & $\begin{array}{c}\text { Bond } \\
\text { strength } \\
\text { /MPa }\end{array}$ & $\begin{array}{c}\text { Specimen } \\
\text { number }\end{array}$ & $\begin{array}{c}\text { Bond } \\
\text { strength } \\
\text { /MPa }\end{array}$ \\
\hline $\mathrm{A} 0$ & 3.01 & $\mathrm{~B} 0$ & 2.45 \\
\hline $\mathrm{A} 1$ & 3.16 & $\mathrm{~B} 1$ & 2.56 \\
\hline $\mathrm{A} 2$ & 3.23 & $\mathrm{~B} 2$ & 2.60 \\
\hline $\mathrm{A} 3$ & 3.35 & $\mathrm{~B} 3$ & 2.72 \\
\hline
\end{tabular}

\section{Test results and analysis}

The relationship between the bond strength of the polymer modified mortar and the interface roughness is shown in Figure 5, As can be seen from the figure, the bonding strength of the polymer modified mortar increases with the increase of the interface roughness. The bonding strength of VAE rubber powder modified mortar is greater than that of styrene-acrylic emulsion modified mortar. In terms of interface bonding performance, VAE rubber powder has a stronger modification effect on mortar. When the roughness is 0.405 , the bonding strength of VAE rubber powder modified mortar is $3.35 \mathrm{MPa}$, compared with the untreated interface, the bonding strength is increased by $11.3 \%$. The bonding strength of styrene-acrylic emulsion modified mortar is $2.72 \mathrm{MPa}$, increased by $11 \%$. Therefore, in engineering repair, when spraying or painting polymer modified mortar on the old mortar, the interface can be properly chiseled to increase the interface roughness, which is conducive to the firm adhesion of the mortar and guarantees the construction quality. 


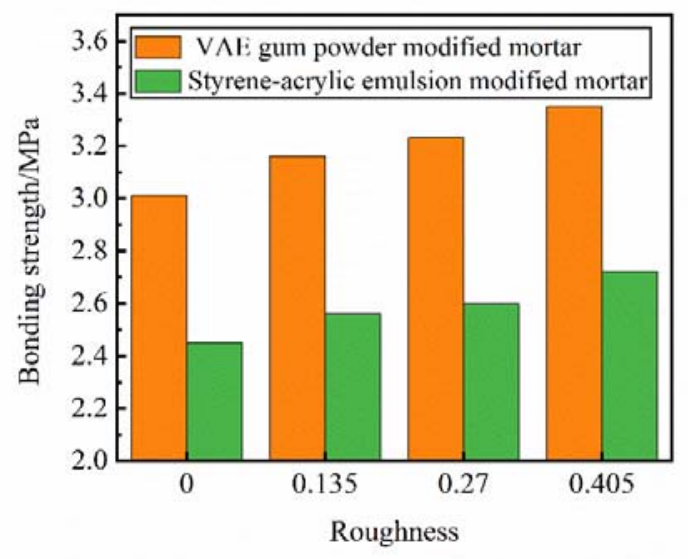

Fig. 5. Relationship between bond strength of polymermodified mortar and interface roughness.

\section{Engineering application of polymer modified mortar}

Polymer-modified mortar is a composite material composed of cement, sand and organic polymers that can be dispersed in water. There is a network structure formed by polymer films. This polymer film structure can not only improve the mortar Flexural strength, toughness and other mechanical properties, and endowed with good durability of mortar. The polymer modified mortar mix ratio and preparation process are similar to ordinary mortar, the shrinkage difference is small, the construction performance is good, and it can adapt to various natural environments. One of the uses of polymer modified mortar is to repair concrete structures. The structures that can be used for repairing include general industrial and civil buildings, marine and port buildings, roads and bridges, underground buildings, etc. Using polymer modified mortar for structural repair can speed up the construction speed, improve the durability of the structure, and also save a lot of money. Therefore, polymer modified mortar has broad application prospects.

VAE rubber powder modified mortar has excellent anti-carbonization, anti-chloride ion corrosion and other properties, can be widely used in the field of concrete anti-corrosion. Adding VAE rubber powder to the mortar can improve the workability of the mortar, reduce the water consumption of the mortar, and improve the compactness and anti-carbonization performance of the mortar. At the same time, VAE rubber powder particles are small and can be filled in the cement hydration product, forming a multi-layer membrane network inside the hardened cement slurry, which can prevent the invasion of oxygen, carbon dioxide, chloride ions, and water. VAE rubber powder modified mortar has excellent anti-carbonization performance, and it has a significant effect on the carbonization of reinforced concrete in reservoirs, hydropower stations, instrument factories and other reinforced concrete. VAE rubber powder modified mortar has excellent anti-corrosion and anti-chloride ion corrosion properties. It is not only suitable for the anti-corrosion and anti-seepage treatment of civil and military buildings, but also suitable for the protection and repair works of highways, bridges, ports and water conservancy projects.

Styrene-acrylic emulsion modified mortar has excellent anti-freezing and anti-seepage properties, and can be used for repairing and anti-seepage treatment of freeze-thaw damage of concrete structures. Adding styrene-acrylic emulsion to the mortar can optimize the internal pore structure of the mortar, reduce the porosity, and improve its frost resistance and impermeability. In northern and high-altitude areas, freeze-thaw damage will accelerate the aging of concrete, reduce the effective bearing area of piles, columns, and slabs, thereby reducing the stability and bearing capacity of structures. Use styrene-acrylic emulsion modified mortar to repair the structure, which can reduce freezethaw damage and prolong its service life. For the water seepage problem of underground caverns, tunnels and other structures, styrene-acrylic emulsion modified mortar with good impermeability can be used for the wall and top to prevent leakage and plugging treatment.

\section{Conclusion}

Polymer modified mortar has a wide range of application fields and prospects. It is an important material for the repair and reinforcement of concrete structures. The structures that can be used for repair and reinforcement include underground engineering, general industrial and civil buildings, hydraulic structures, marine port structures, and underground buildings, structures, roads and bridges. VAE rubber powder modified mortar can be widely used in the field of concrete anticorrosion, and styrene-acrylic emulsion modified mortar can be used for repairing and anti-seepage treatment of concrete structure freeze-thaw damage. In practical engineering applications, the interface can be properly chiseled to increase the interface roughness, which is conducive to the strong adhesion of the polymer modified mortar.

\section{References}

1. E. Knapen, D. Van Gemert. Polymer film formation in cement mortars modified with water-soluble polymers[J]. Cement and Concrete Composites, 2015, 58 .

2. Tsai-Lung Weng. Evaluation of cementitious repair mortars modified with polymers. 2017, 9(1):77-82.

3. Urgessa Girum, Choi Ki-Bong, Yeon Jung Heum. Internal Relative Humidity, Autogenous Shrinkage, and Strength of Cement Mortar Modified with Superabsorbent Polymers[J]. Polymers, 2018, 10(10)

4. A. Brenna, F. Bolzoni, S. Beretta, et al. Long-term chloride-induced corrosion monitoring of reinforced concrete coated with commercial polymer-modified 
mortar and polymeric coatings $[\mathrm{J}]$. Construction and Building Materials, 2013, 48.

5. Magdy M. Khattab. Effect of gamma irradiation on polymer modified white sand cement mortar composites $[\mathrm{J}]$. Journal of Industrial and Engineering Chemistry, 2014, 20(1).

6. Wan-Ki Kim, Deuk-Mo Kim, Hwa-Sung Ryu, et al. Properties of Hardener-Free Epoxy-Modified Mortars utilizing Pyrolysis Tar Replacement[J]. Construction and Building Materials, 2017, 144.

7. Pan Wei, Duan Yufang. Research on the properties of polymer modified rigid waterproof mortar [J]. New Building Materials, 2015, 42(2): 30-32.

8. Shaker FA, Ei-Dieb AS, Reda M M. Durability of Styrene-butadiene latex modified concrete[J]. Cement and Concrete Research, 1997, 27(3): 711-714.

9. Pan Zhengkai, Zhang Jun. The effect of three emulsions on the mechanics and impermeability of polymer cement waterproof mortar [J]. China Building Waterproof, 2015, (12): 7-9.

10. G. Neşer, A.S. Bayram, K.T. Gürsel, et al. On the polymer modified cement mortars with different lightweight aggregates in marine environment[J]. Materialwissenschaft und Werkstofftechnik, 2018, 49(7). 